\title{
ANALISIS PENGELOLAAN WISATAWAN MANCANEGARA DI DESTINASI PARIWISATA NUSA LEMBONGAN KABUPATEN KLUNGKUNG BALI
}

\author{
Dewa Ayu Made Lily Dianasari ${ }^{1 *}$, Ni Made Tirtawati ${ }^{2}$, Hanugerah Kristiono Liestiandre ${ }^{3}$, Ida \\ Bagus Putra Negarayana ${ }^{4}$, I Gede Gian Saputra ${ }^{5}$ \\ 1,2,3,4,5 Program Studi Manajemen Kepariwisataan, Politeknik Pariwisata Bali \\ Jl. Dharmawangsa Kampial, Nusa Dua Bali \\ 1*)lily.dianasari@ppb.ac.id, 2tirtastp@yahoo.co.id,33hanugerah@ppb.ac.id, \\ ${ }^{4}$ negarayana@ppb.ac.id, 5giansaputra@ppb.ac.id \\ ${ }^{*}$ Corresponding author
}

\begin{tabular}{l|l|l} 
Received: Februari, 2020 & Accepted: Maret, 2020 & Published: Maret. 2020
\end{tabular}

\begin{abstract}
The purpose of this study is to determine the perceptions of tourists towards Nusa Lembongan as a destination and the management of tourists in Nusa Lembongan. The determination of the sample in this study was to obtain data on the characteristics of tourists visiting Nusa Lembongan with 103 respondents using qualitative analysis techniques. The results of the study are tourists' perceptions of Nusa Lembongan from indicators of awareness 58.43\% (agree), attractiveness 65.2\% (agree), availability 63.08\% (agree), accessibility $62.95 \%$ (agree), destination appreciation (66.3\%), assurance 58.2\%, activity 45.6\%, appearance $58.3 \%$ (agree).
\end{abstract}

Keywords: perception, tourist, destination, Nusa Lembongan

\begin{abstract}
Abstrak
Tujuan dari penelitian ini adalah untuk mengetahui persepsi wisatawan terhadap destinasi pariwisata Nusa Lembongan dan pengelolaan wisatawan mancanegara di destinasi pariwisata Nusa Lembongan. Penentuan sampel pada penelitian ini adalah untuk mendapatkan data mengenai karakteristik wisatawan yang berkunjung ke Nusa Lembongan sebanyak 103 responden dengan menggunakan teknik analisis kualitatif. Hasil penelitian adalah persepsi wisatawan terhadap destinasi Nusa Lembongan dari indikator awareness 58,43\% (setuju), attractiveness 65,2 \% (setuju), availability 63,08\% (setuju), accessibility $62,95 \%$ (setuju), destination appreciation (66,3\%), assurance 58,2\%,

activity $45,6 \%$, appearance $58,3 \%$ (setuju)
\end{abstract}

Kata Kunci: persepsi, wisatawan, destinasi, Nusa Lembongan

\section{PENDAHULUAN}

Nusa Lembongan banyak dipasarkan oleh pelaku wisata baik melalui media offline maupun online, sehingga kunjungan wisatawan terus mengalami peningkatan. Nusa Lembongan memiliki potensi yang besar terutama keindahan laut dan pantainya yang menjadi favorit wisatawan untuk mendokumentasikan 
pengalaman

perjalanannya.

Berkembangnya Nusa Lembongan tidak terlepas dari gencarnya promosi tentang keunikan daerahnya baik di media sosial maupun media pemasaran konvensional. Promosi inipun diterima oleh pasar wisatawan di Bali terutama yang telah melakukan kunjungan ulang atau lebih dikenal dengan istilah repeater.

Nusa Lembongan memiliki beragam aktivitas yang dapat memberikan pengalaman bagi wisatawan seperti water sport, mangrove tour dan adanya spot untuk berswafoto misalnya Devil Tears, Dream Beach dan juga jembatan kuning yang menjadi ikon wisata selain berfungsi menjadi penghubung Nusa Lembongan dengan Nusa Ceningan.

Fenomena pariwisata di Nusa Lembongan tentunya memberikan peluang segar bagi masyarakat Bali khususnya masyarakat di Nusa Lembongan. Hal ini dikarenakan wisatawan banyak menghabiskan uangnya ketika berkunjung ke Nusa Lembongan. Namun, perlu menjadi perhatian bagi stakeholder pariwisata saat ini, kenyamanan Nusa Lembongan sebagai destinasi pariwisata mulai diragukan oleh sebagaian wisatawan yang telah berkunjung. Hal ini dapat terlihat dari review wisatawan yang sempat mengalami kekecewaan karena terlalu banyak wisatawan mancanegara ataupun karena lingkungan yang tidak bersih. Kepuasan wisatawan mancanegara merupakan factor penting dalam menjadikan pariwisata di Nusa Lembongan berkelanjutan. Untuk menciptakan kepuasan wisatawan diperlukan suatu pengelolaan pariwisata secara holistik. Salah satu wujudnya dapat dilakukan dengan mengimplementasikan strategi pengelolaan wisatawan mancanegara (Visitor Management) di destinasi pariwisata Nusa Lembongan.

\section{TEORI DAN KONSEP}

\subsection{Visitor Management}

Pengelolaan wisatawan mancanegara (visitor management) fokus pada suatu destinasi wisata baik itu berupa situs peninggalan sejarah maupun daya tarik wisata berbasis alam (taman nasional) yang berorientasi untuk memaksimalkan kualitas pengalaman kunjungan, serta meminimalkan dampak kunjungan pada objek peninggalan sejarah tersebut (Mc Arthur, 1993). Manajemen wisatawan mancanegara juga merupakan kegiatan yang bersifat administratif untuk memelihara kualitas sumberdaya wisata alam dan kualitas pengalaman kunjungan Eagles dan Mc Cool (2002).

Manajemen wisatawan mancanegara pada dasarnya adalah keterkaitan yang harmonis antara wisatawan mancanegara (visitor), objek (place), dan pengelola/ tuan rumah (host). Keterkaitan yang harmonis tersebut apabila dikelola dengan baik akan mampu mewujudkan keberhasilan manajemen wisatawan mancanegara yang sesungguhnya yaitu pengelolaan yang mampu memberikan nilai lebih pada objek, sebagaimana diutarakan oleh Davidson dan Maitland (1997) berikut ini: kualitas pengalaman kunjungan, meningkatkan reputasi dan citra objek/destinasi yang dikunjungi, menciptakan peningkatan kualitas lingkungan objek, memaksimalkan peluang ekonomis pariwisata, meminimalkan dampak negatif khususnya terhadap komunitas setempat, meningkatkan lama tinggal, meningkatkan intensitas kunjungan (off season visits) sehingga dapat mengurangi waktu peak season, mengurangi beban yang melebihi kapasitas daya tampung situs, dan menguatkan nilai-nilai kelokalan yang ada.

\subsection{Sustainable Tourism}

Pengembangan pariwisata berkelanjutan menurut Weaver (2000), didefinisikan sebagai berikut "sustainable tourism development is tourism development that meet the needs of the present without compromising the ability of future generation to meet their own needs." Sedangkan Sugiama (2011) mengemukakan bahwa pariwisata 
Dianasari, Tirtawati,. Liestiandre, Negarayana, Saputra

berkelanjutan sering disebut dengan alternative tourism adalah kepariwisataan yang dikembangkan dengan memperhatikan kelestarian lingkungan alam dan budaya masyarakat setempat sehingga dapat diwariskan untuk generasi mendatang. Pengertian tersebut menjelaskan bahwa pariwisata dikembangkan berdasarkan untuk memenuhi kebutuhan sekarang, namun tidak juga mengorbankan kebutuhan masa depan yang akan dinikmati oleh generasi penerus, sehingga perlunya menjaga kelestarian lingkungan alam. Untuk itu, pengembangan pariwisata berkelanjutan haruslah sesuai dengan prinsip-prinsip dasar pengelolaan pariwisata berkelanjutan.

\subsection{Tourism Area Life Cycle}

Menurut Butler (2006) terdapat beberapa fase pengembangan pariwisata (siklus hidup area pariwisata) yang membawa implikasi serta dampak yang berbeda. Nusa Lembongan terlihat pengembangan pariwisata masih memerlukan upaya yang mampu membawa lingkungan kearah yang lebih berkelanjutan. Bila dicermati, Nusa Lembongan telah menempati fase Involvement (Pelibatan). Hal ini ditandai dari meningkatnya jumlah kunjungan wisatawan, sehingga masyarakat lokal mulai menyediakan berbagai fasilitas pariwisata. Kontak antara wisatawan dengan masyarakat tinggi dan masyarakat mulai mengubah pola-pola sosial yang ada untuk merespon perubahan ekonomi yang terjadi. Promosi Nusa Lembongan juga sangat encar dilakukan oleh para stakeholder yang menjadikan Nusa Lembongan kian menarik bagi wisatawan. Namun, hal ini bila tidak diantisipasi, tidak menutup kemungkinan Nusa Lembongan bisa langsung ditinggalkan oleh wisatawan. Hal ini dikarenakan kesiapan masyarakat dan kesadaran tentang kelestarian lingkungan masih sangat minim. Oleh karena itu, teori ini akan digunakan untuk membahas dampak pariwisata yang terjadi di Nusa Lembongan dimana pengembangan pariwisata berkelanjutan sangat diperlukan untuk menciptakan pariwisata yang memperhatikan lingkungan.

\section{METODE PENELITIAN}

Penelitian ini menggunakan pendekatan kualitatif untuk mendapatkan data dan hasil penelitian. Pengumpulan data dilakukan dengan metode observasi dengan melakukan wawancara dan penyebaran kuesioner kepada wisatawan yang berkunjung ke Nusa Lembongan sebanyak

103 responden secara accidental sampling. Wawancara dilakukan dengan stakeholder pariwisata Nusa Lembongan yang dilihat dari aspek ekonomi dan sosial budaya yaitu pengelola/ pengusaha pariwisata, masyarakat lokal dan pemerintah. Terdapat pula informan dari stakeholders/ pakar terdiri dari unsur (akademisi dan LSM). Teknik penentuan informan dilakukan dengan cara purposive sampling (bertujuan khusus) dan snowball dengan dasar pertimbangan yang ditentukan menjadi informan adalah orang yang memang mengetahui betul kondisi Nusa Lembongan dan pernah mengunjungi Nusa Lembongan untuk tujuan wisata

\section{HASIL PENELITIAN}

Karakteristik wisatawan mancanegara yang berkunjung ke Nusa Lembongan berdasarkan asal negara dapat di lihat pada gambar 1. 
Dianasari, Tirtawati,. Liestiandre, Negarayana, Saputra
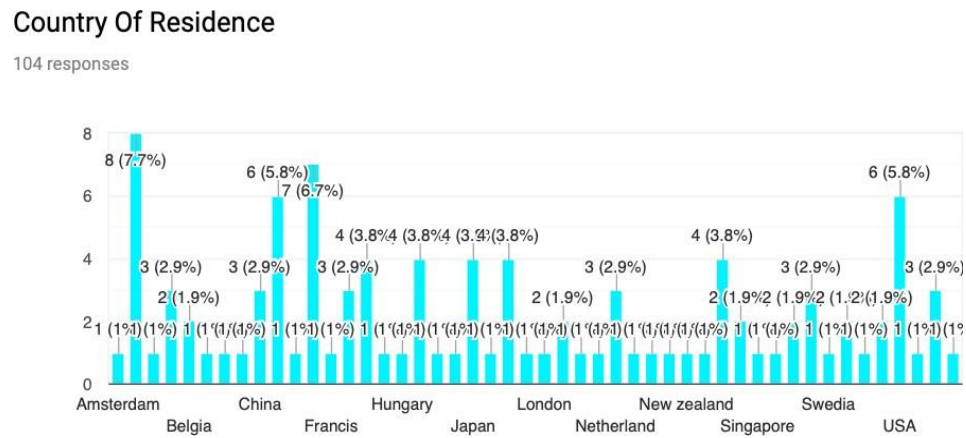

Wisatawan yang berkunjung ke Nusa Lem- bongan paling banyak berasal dari Amsterdam atau Belanda. Hal ini ditunjukan dari hasil sur- vei yang dilakukan ke 103 responden sebanyak 7,7\% berasal dari Amsterdam dan paling sedikit berdasarkan survei yang dilakukan adalah beras- al dari Swedia yaitu sebanyak 1,2\%. Sedangkan profil wisatawan mancanegara yang berkunjung ke Nusa Lembongan dapat di lihat pada Tabel 1.

Tabel 1. Profil Wisatawan yang berkunjung ke Nusa Lembongan [Sumber : Data Penelitian, 2019]

\begin{tabular}{|c|c|c|c|}
\hline No & Profile & Keterangan & $\begin{array}{l}\text { Pers } \\
\text { entase }(\%)\end{array}$ \\
\hline \multirow[t]{3}{*}{1} & Jenis & Male & 45,2 \\
\hline & & Female & 54,8 \\
\hline & Total & & 100 \\
\hline \multirow[t]{6}{*}{2} & Umur & $\underline{15-24}$ & 26 \\
\hline & & $\overline{25-34}$ & 51 \\
\hline & & $35-44$ & 15,4 \\
\hline & & $45-55$ & 7,7 \\
\hline & & $\geq 55$ & - \\
\hline & Total & & 100 \\
\hline \multirow[t]{6}{*}{3} & Pendidikan & SD & - \\
\hline & & SMP & 1,2 \\
\hline & & SMA & 20,2 \\
\hline & & Sarjana & 56,7 \\
\hline & & $\mathrm{S} 2$ & 22,1 \\
\hline & Total & & 100 \\
\hline \multirow[t]{7}{*}{4} & Pekerjaan & Pensiun & 19,2 \\
\hline & & Wirausaha & 19,2 \\
\hline & & Pegawai & 41,3 \\
\hline & & Pelajar & 17,3 \\
\hline & & Ibu Rumah & 3 \\
\hline & & Tangga & \\
\hline & Total & & 100 \\
\hline \multirow[t]{5}{*}{5} & Tujuan & Liburan & 90,4 \\
\hline & & Bisnis & 7 \\
\hline & & Penelitian & 1,3 \\
\hline & & $\begin{array}{l}\text { Mengunjungi } \\
\text { teman }\end{array}$ & 1,3 \\
\hline & Total & & 100 \\
\hline \multirow[t]{2}{*}{6} & $\begin{array}{l}\text { R e k a n } \\
\text { Berkunjung }\end{array}$ & Sendiri & 10,6 \\
\hline & & Teman & 67,3 \\
\hline
\end{tabular}


Dianasari, Tirtawati,. Liestiandre, Negarayana, Saputra

\begin{tabular}{|c|c|c|c|}
\hline \multirow{6}{*}{7} & & $\begin{array}{l}\text { Keluarga } \\
\text { Group }\end{array}$ & $\begin{array}{l}18,3 \\
3,8\end{array}$ \\
\hline & Total & & 100 \\
\hline & Berkunjung & 1 kali & 82,7 \\
\hline & & 2 kali & 14,4 \\
\hline & & $\begin{array}{l}3 \text { kali atau } \\
\text { lebih }\end{array}$ & 2,9 \\
\hline & Total & & 100 \\
\hline
\end{tabular}

Berdasarkan Tabel 1 dijelaskan bahwa wisatawan mancanegara yang berkunjung ke Nusa Lembongan terbanyak adalah berjenis kelamin perempuan $(54,8 \%)$ dengan usia $25-34$ tahun (51\%), tingkat pendidikan Sarjana/Diploma $(56,7 \%)$ dan memiliki pekerjaan sebagai pegawai atau staff $(41,3 \%)$. Wisatawan mancanegara yang berkunjung ke Nusa Lembongan sebagian besar adalah bertujuan untuk berlibur $(90,4 \%)$, bersama teman $(67,3 \%)$ dan kunjungan mereka ke Nusa Lembongan adalah untuk pertama kali $(82,7 \%)$ serta mengetahui informasi Nusa Lembongan dari internet/media social $(76,9 \%)$. Persepsi wisatawan mancanegara yang berkunjunga ke Nusa Lembongan dapat dilihat pada Tabel 2.

Tabel 2. Persepsi wisatawan terhadap Nusa Lembongan

[Sumber : Data Penelitian, 2019]

\begin{tabular}{|c|c|c|c|c|c|}
\hline \multirow[t]{2}{*}{ No } & \multirow[t]{2}{*}{ Indikator } & \multicolumn{4}{|c|}{ Persentase } \\
\hline & & $\begin{array}{l}\text { Sangat Ti- } \\
\text { dak Setuju }\end{array}$ & $\begin{array}{l}\text { Tidak } \\
\text { Setuju }\end{array}$ & Setuju & $\begin{array}{l}\text { Sangat } \\
\text { Setuju }\end{array}$ \\
\hline \multicolumn{6}{|c|}{ Awareness } \\
\hline 1 & Lokasi yang strategis & 1 & 8,7 & 62,5 & 27,8 \\
\hline 2 & Keunikan & 1 & 5,7 & 38,5 & 54,8 \\
\hline 3 & Harga Tiket & 1,9 & 10,6 & 65,4 & 22,1 \\
\hline 4 & Kemudahan Informasi & 1 & 2,9 & 67,3 & 28,8 \\
\hline & Rata-rata & 1,23 & 6,98 & 58,43 & 33,38 \\
\hline \multicolumn{6}{|c|}{ Attractiveness } \\
\hline 1 & Keragaman & 1 & 9,6 & 69,2 & 20,2 \\
\hline 2 & Informasi & 3,8 & 8,7 & 69,2 & 18,3 \\
\hline 3 & Kemudahan Informasi & 1,9 & 11,5 & 66,4 & 20,2 \\
\hline 4 & Akomodasi, Restauran dan Transportasi & 1 & 1,9 & 70,2 & 26,9 \\
\hline 5 & Citra & 1,9 & 1 & 51 & 46,1 \\
\hline & Rata-rata & 1,92 & 6,54 & 65,20 & 26,34 \\
\hline \multicolumn{6}{|c|}{ Availability } \\
\hline 1 & Profesionalitas Pegawai & 1,9 & 1,9 & 66,4 & 29,8 \\
\hline 2 & $\begin{array}{l}\text { Kemudahan Informasi Online dan } \\
\text { Offline }\end{array}$ & 1 & 5,7 & 59,6 & 33,7 \\
\hline 3 & Pesanan Tiket & 1 & 3,8 & 59,6 & 35,6 \\
\hline 4 & Kondisi Fasilitas dan Informasi & 1 & 19,2 & 61,5 & 18,3 \\
\hline 5 & Tempat saran & 2,9 & 13,5 & 68,3 & 15,3 \\
\hline & Rata-rata & 1,56 & 8,82 & 63,08 & 26,54 \\
\hline \multicolumn{6}{|c|}{ Aksesibilitas } \\
\hline 1 & Kemudahan Transport & 2,9 & 25 & 51,9 & 20,2 \\
\hline 2 & Papan Informasi & 2,9 & 17,3 & 61,5 & 18,3 \\
\hline
\end{tabular}


Analis Pengelolaan Wisatawan Mancanegara di Destinasi Pariwisata Nusa Lembongan Kabupaten Klungkung, Bali

Dianasari, Tirtawati,. Liestiandre, Negarayana, Saputra

\begin{tabular}{|c|c|c|c|c|c|}
\hline & Rata-rata & 2,9 & 21,15 & 56,7 & 19,25 \\
\hline \multicolumn{6}{|c|}{ Destination } \\
\hline 1 & Melihat pemandangan dengan jelas & 1 & 4,8 & 66,3 & 27,9 \\
\hline \multicolumn{6}{|c|}{ Assurance } \\
\hline 1 & Petugas yang responsif & 1,9 & 10,6 & 72,1 & 15,4 \\
\hline 2 & Keramahan Masyarakat & 1,9 & 0 & 44,2 & 53,8 \\
\hline & Rata-rata & 1,9 & 5,3 & 58,2 & 34,6 \\
\hline \multicolumn{6}{|c|}{ Activity } \\
\hline 1 & Keindahan Atraksi & 1 & 1 & 32,6 & 65,4 \\
\hline 2 & $\begin{array}{l}\text { Ketersediaan makanan local di } \\
\text { atraksi }\end{array}$ & 2,9 & 7,7 & 58,7 & 30,8 \\
\hline & Rata-rata & 1,95 & 4,35 & 45,6 & 48,1 \\
\hline \multicolumn{6}{|c|}{ Apperance } \\
\hline 1 & Keamanan di atraksi wisata & 1 & 1 & 63,5 & 34,6 \\
\hline 2 & Kebersihan di atraksi wisata & 1,9 & 7,7 & 65,4 & 25 \\
\hline 3 & Pengalaman Perjalanan & 1,9 & 0 & 45,2 & 52,9 \\
\hline & Rata-rata & 1,6 & 2,9 & 58,03 & 37,47 \\
\hline
\end{tabular}

Berdasarkan Tabel 2 dapat dijelaskan bahwa persepsi wisatawan terhadap destinasi pariwisata Nusa Lembongan, dikaji dari delapan indikator komponen destinasi diantaranya:

Persepsi wisatawan mancanegara terhadap awareness Nusa Lembongan. menyatakan bahwa atraksi atau daya tarik wisata yang ada di Nusa Lembongan letaknya strategis. Wisatawan menyatakan bahwa setiap atraksi wisata memiliki keunikan sendiri. Harga tiket untuk aktivitas wisata, tiket hotel serta harga jasa transportasi yang ditawarkan munurut wisatawan mancanegara sesuai dengan yang didapatkan. Rata-rata wisatawan menyatakan sangat setuju untuk seluruh aspek awareness yaitu 58,43\%.

Persepsi wisatawan mancanegara terhadap daya tarik Nusa Lembongan, dimana menurut wisatawan banyak atraksi wisata yang ditawarkan, di daya tarik wisata juga tersedia infomasi wisata, wisatawan juga mudah menemukan akses menuju daya tarik wisata, terdapat akomodasi, restoran dan transportasi di daya tarik wisata, dan atraksi atau daya tarik wisata di Nusa Lembongan memiliki citra yang baik. Rata-rata persepsi wisatawan mancanegara terhadap indikator attractiveness menyatakan setuju yaitu sebesar $65,20 \%$.

Persepsi wisatawan mancanegara availability Nusa Lembongan, menyatakan bahwa di Nusa Lembongan tersedia berbagai fasilitas penunjang pariwisata dengan kondisi yang cukup baik seperti; staf yang ramah, kemudahan menemukan informasi baik online maupun offline, tersedia fasilitas dan infrastruktur yang sangat bagus. Persepsi wisatawan terhadap destinasi Nusa Lembongan dari indikator availability adalah 63,08\% (setuju).

Persepsi wisatawan mancanegara terhada accessibility Nusa Lembongan, yaitu wisatawan mudah untuk menemukan transportasi dan adanya papan informasi di daya tarik wisata memudahkan wisatawan untuk mencari lokasi- lokasi yang menjadi tujuan mereka. Nilai persepsi wisatawan adalah $56,7 \%$ (setuju)

Persepsi wisatawan mancanegara terhadap destination appreciation dengan nilai $66,3 \%$ menurut wisatawan Nusa Lembongan memberikan dan menawarkan keindahan pemandangan alam yang luar biasa

Persepsi terhadap Assurance 58,2\% menurut wisatawan mancanegara petugas keamanan wisata bersikap 
sangat responsif dalam menangani keluhan wisatawan dan masyarakat sangar ramah menerima kunjungan wisatawan ke Nusa Lembongan.

Persepsi Wisatawan mancanegara terhadap Activity, menurut wisatawan atraksi wisata di Nusa Lembongann menawarkan pemandangan dan panorama yang indah. Wisatawan mancanegara juga dapat mengkonsumsi kuliner lokal di Nusa Lembongan. 45,6\%

Persepsi wisatawan mancanegara terhadap Appearance adalah 58,03\% (setuju) menurut mereka merasa aman berada di atraksi wisata, kebersihan atraksi wisata sangat bagus dan merasakan bahwa mereka mendapatkan perjalanan yang menyenangkan dan tidak terlupakan di daya tarik wisata yang ada di Nusa Lembongan.

\subsection{Pengelolaan Wisatawan di Nusa Lembongan}

Pengelolaan wisatawan di destinasi pariwisata Nusa Lembongan, dikaji dari dua aspek diantaranya:

1) Pola Perjalanan Pengunjung di Nusa Lembongan yaitu pertama Pengunjung akan melakukan penyeberangan menggunakan fast boat. Kedua Pengunjung akan menyewa moda transportasi untuk mobilisasi selama di Nusa Lembongan. Sedangkan pola aktivitas Pengunjung di Nusa lembongan yaitu perjalanan satu hari dengan pilihan aktivitas yaitu wisata keliling pulau (tour the island) serta water activity atau perjalanan dua hari.

2) Kualitas Fasilitas Pengunjung di Nusa Lembongan memiliki beberapa hal yang perlu diperhatihan yaitu pembanguanan dermaga, peningkatan standar kualitas kendaraan, peningkatan standar kualitas infrastruktur serta peningkatan kualitas fasilitas pendukung.

\section{KESIMPULAN}

Berdasarkan penjelasan diatas maka dapat disimpulkan bahwa persepsi wisatawan terhadap destinasi Nusa Lembongan dari indikator awareness, attractiveness, availability, accessibility, destination appreciation, assurance, activity, dan appearance adalah wisatawan menyatakan setuju dengan persentase diatas 50 persen dan pengelolan wisatawan dilihat dari pola perjalanannya adalah sebagian besar menggunakan fast boat dan melakukan aktifitas satu hari dengan jenis kegiatan keliling pulau dan snorkelling. Rekomendasi pengelolaan wisatawan yang berkunjung ke Nusa Lembongan adalah belum memiliki system tata kelola yang jelas sehingga berimplikasi terhadap ketidakteraturan pola perjalanan wisatawan, maka perlu dibentuk badan pengelola baik pemerintahan desa maupun pemerintah daerah.

\section{DAFTAR PUSTAKA}

Butler. R.W. (2006). The Concept of Tourism Area Cycle of Evolution: Implications for the Management of resources. The Canadian Geographer.

Candrea, A.N. \& Ispas, A. (2009). Visitor Management, A Tool For Sustainable Tourism Development In Protected Areas. Bulletin of The Transilvania University Of BrașOv • Vol. 2 (51) 2009 Series V: Economic Sciences

Davidson, R., \& Maitland, R. (1997). Tourism Destination. Houder \& Stoughton. London.

Eagles, P.F.J, McCool, S.F. \& Christopher D. Haynes. 2002. Sustainable Tourism in Protected Areas Guidelines for Planning and Management. United Kingdom: International Union for Conservation of Nature and Natural Resources.

Master, David, Socoot Peter, barroe, Graham. 2002. Sustanable Visitor Management System: A Discussion Paper.

Sugiama, A. G. (2011). Ecotourism: Pengembangan Pariwisata Berbasis Konservasi Alam. Guardaya Intimarta, Bandung. 
Dianasari, Tirtawati,. Liestiandre, Negarayana, Saputra

Sugiyono. 2009. Metode Penelitian

Kuantitatif, Kualitatif dan $R \& D$.

Bandung: CV Alfabeta.

Weaver, David \& Opperman, M. (2000).

Tourism Management, John Wiley \&

Sons, Australia. 